\title{
The Role of Intangibles in the Creation of Company Value
}

\author{
Graziella Sicoli ${ }^{1}$ \\ ${ }^{1}$ Assistant professor in accounting, Department of Business Science and Law, University of Calabria, Italy \\ Correspondence: Graziella Sicoli, Assistant professor in accounting, Department of Business Science and Law, \\ University of Calabria, Italy. E-mail: graziella.sicoli@unical.it
}

Received: May 15, 2018

doi:10.5539/ijbm.v13n9p161
Accepted: June 21, 2018

Online Published: August 1, 2018

URL: https://doi.org/10.5539/ijbm.v13n9p161

\begin{abstract}
The interest of the business economists in intangibles is growing and to this day the topic remains discussed both with reference to the nature of these resources, and to their role, their contribution in terms of value creation. Intangibles are one of the main sources of companies' competitive advantage (Tanfous, 2013). The definition and classification of intangibles is still an open question. Among intangibles, knowledge assumes a fundamental role. As stated by Sveiby (Sveiby, 1997) intellectual capital is 'knowledge that can be converted into value. In fact, only the value of intangibles offers a comapny the possibility of differentiating itself from its competitors, and as stated by Stewart the differences among firms is played out by the correect management of intangible resources, which allow them to overcome competitors (Stewart, 1997). The aim of this work of the work is to carry out an analysis of the literature with reference to the definitions and classifications offered both nationally and internationally, their role in the company and their contribution in terms of value creation. To understand the sources of competitive advantage that intangibles generate it is necessary to build a model based on the statement that the resources of the company are immobile and heterogeneous. (Barney, 1991). Every enterprise must create the structures that help them to accumulate knowledge capital and create intangible assets systematically and to convert it to value for their customers in order to gain a competitive edge and create long-term shareholder value (Lev, 2003). This paper confirms the theory that adequate investments in intangibles exercises a positive influence on company performance; for the future, with the purpose of creating company value, we believe it opportune to consider the good association between intangibles and the various components of immaterial resources; this association will be able to guarantee not only the creation of value for the shareholders but for all the subjects directly and indirectly involved in the life of the company as well as the survival and reputation of the company itself. The paper offers adequate points for reflection for future examination regarding the relationship between investments achieved in intangibles and the creation of company value. Moreover, it confirms what the was previously stated, that up to now, studies on intangibles have not arrived at a universally accepted definition. Therefore, we hope for this in the near future.
\end{abstract}

Keywords: Intangible, Value creation, competitive advantage, knowledge

\section{Introduction}

The issue of intangibles is a complex and articulate phenomenon, defined not only as typically economic, because it is linked to the growth and the procreation of company value, but also as typically modern because it is at the bottom of the development of the so-called advanced economies. Many studies that concern company management look at knowledge as one of the main factors of success for the company and consider activities of knowledge management essential for its survival (Bontis, 2002). The importance that intangible resources acquired is the result of the relationship between two important forces: the structural changes of companies, constituted by the greater competition to which they are subjected; the considerable information and technology innovations that led companies to compete on a global scale (Bresciani \& Ferraris, 2012). Both of these forces changed the way of doing business and made intangible resources become determining factors in the process of creating company value. Lee and Chen (Lee and Chen, 2009) observed that research and development expenditures lead to two types of effect on the company's value creation. In their study, they observed that low or moderate levels of R\&D expenditure lead to negative returns from shares while on the other hand, high levels of R\&D expenditure lead to positive returns (Miller \& Mathisen, 2008).

The interest that business economists have in the issue of intangible resources (identified henceforth intangibles) is constantly growing and to this day it remains a very controversial subject with reference to the nature of these 
resources, to their role, and above all to their contribution in terms of value creation. The company, in order to confront changes and, at the same time, maintain a position of competitive advantage, must seize the presented opportunities and organize its resources efficiently. In this context, the focus is not only on physical resources, but also on intangibles.

Several studies provide empirical evidence for the hypothesis of the potentiality of intangibles in the generation of future economic benefits for companies (value creation and economic performance). Hall et al. found positive relationships between the number of patents and the market value of the company (Hall et al., 2001); Villalonga, in turn, investigated the influence of intangible resources on the superior performance of North American companies and found in his research that intangibles play an effective role in sustainable competitive advantage, thus generating superior economic performance, as foreseen by the resource-based view (Villalonga, 2004; Grant, 1991).

Before mentioning intangibles, it is necessary to analyze the definition of these resources, while being aware of the complexity of the topic and the numerous contributions presented in the literature. Even today, there is no unique classification and definition of intangibles. The objective that this work aims to achieve consists of carrying out a review of the literature with reference to the possible definitions and classifications offered by the economic-business doctrine on the subject of intangibles, both nationally and internationally. Intellectual capital covers a large part of the intangibles; it is understood in its broader meaning of internal (skills, competences and capacities) and external (image, brand, customer satisfaction) knowledge stock of an organization, that allows a complex of material, financial and human resources to be transformed into a structured and coordinated system which is capable of creating value for stakeholders through the achievement of competitive advantages. The correct management of intellectual Capital together with that of physical capital guarantees a sustainable competitive advantage at the base of the creation of company value (Bernard, 2005). Even though a number of theoretical works have stressed the strategic importance as well as the role of intangible resources as key value drivers for the company's competitiveness (Edvinsson \& Malone, 1997; Diefenbach, 2006); there is still a lack in approaches that evaluate the mechanism by which they contribute to create value (Carlucci \& Schiuma, 2007). This is because of the idiosyncratic nature of these assets (Barney, 1991). As a result, more studies are needed in order to improve the relationship between intangible assets, the way these assets are clustered and their role in value creation resources

\section{Intangible Resources and Immaterial Resources}

Before identifying the broad category of intangible resources, it is essential to pay attention to the distinction between intangible and immaterial resources. These terms are often used as synonyms. In the same way, the terms "intangible resource", "immaterial resource", "invisible resource" and "intangible assets" are used as synonyms and to indicate, in a single category, all the goods without physical consistency that do not meet the requirement of materiality; in this way, however, it has ended up including resources that are very different from one another in the same classification. Immateriality is a phenomenon composed of both intangible and immaterial elements. It is of the utmost importance to accept a definition of immaterial resources that is capable of underlining the contribution of these assets to the production of corporate value and, at the same time, making a primary distinction between these latter and intangible resources (Ahonen, 2000; Rullani, 1992). Immaterial assets are autonomously identifiable and evaluable, even if with methods and criteria that are not yet well defined, while intangible resources do not possess this character of autonomy. Immateriality refers to the absence of physical or financial consistency, while intangibility refers to the difficulties encountered in defining the object and its characteristics. Immaterial assets may have varying degrees of intangibility. A widely diffused definition, which is also acknowledged in the accounting standard IAS 38, states that immaterial asset, understood as economic asset, expresses an expectation towards future benefits, without possessing material substance of a physical or financial nature (IAS 38, 2000); Specifically, immaterial assets are all those resources that generate long-term utilities of an immaterial nature that are presented inside the company through acquisitions or self-constructions (Dameri, 2003), for example: brands, patents, software, aslicenses. Ochs considers intangible investment as a «dynamic intangible investment which incorporates a share of dominant knowledge that contributes in a specific or in a process way to the competitiveness and to the company value» (Ochs, 1995).

The naming of intangible goods instead, refers to resources controlled and used by the company, still can hardly be exchanged with a third party or subject to autonomous evaluation; it is the case of elements such as knowledge, experience, trust, reputation on the market etc.. More specifically, it is mentioned immateriality to refer to elements without physical materiality, while using the term intangibility when referring to resources that are difficult to define and/or determine with certainty and precision due to the lack of a monetary value. The 
characteristic of intangibility can be traced back to resources that are difficult to identify and measure in a certain way according to what traditional accounting methods suggest. The most accredited definition of "intangible assets" is proposed by international accounting standards. The IAS 38 specifies as follows: "Intangible assets are defined as identifiable, non-monetary assets without physical consistency, controlled by the company as a result of past events, from which future economic benefits are expected for the company itself". According to the IASB, the fundamental and discriminating characteristic of intangible asset is its "identifiability" within the working capital. The requirement of identifiability is satisfied if the asset, besides being separable, derives from a contract or other legal rights. The asset is separable if it can be sold, transferred or leased through an independent legal transaction. All the other assets, which are identifiable and measurable but not transferable, are part of the so-called internal goodwill. The requirement of identifiability does not necessarily imply that of transferability. In fact, some immaterial values, however identifiable, are so correlated and conditioned in their own value by belonging to the company that a separation cannot be even hypothesized. To reduce the proposed definitions to extreme synthesis, we refer to the classification offered by Manca (Manca, 2005) as follows:

1. Internal company resources that cannot be autonomously measured and transferred, which contain all those immaterial production conditions that contribute to foster and integrate the value of goodwill. An example of this is the skills of the personnel, the organizational structure of which the company is provided with, etc;

2. Measurable and transferable internal company resources that refer to all immaterial assets can be sold autonomously, and of which value can be measured reliably. The brands, patents and so on are included in this category;

3. Measurable and transferable external resources that relate to assets acquired through the subsistence of a cost and included among immaterial fixed assets (software, patents). Naturally such assets can be sold;

4. External company resources, transferable and non-measurable autonomously, that are non-quantifiable individually and transferable together with the business complex of which they are an integral part following from extraordinary operations. Basically, they include the same resources referred to in point 1) that are acquired in the context of transferring company or company branches.

Intangibles, despite having the impossibility of reaching a physical determination in common with immaterial assets, do not express rights protected by law. In fact, there are intangible assets that are effectively protected and actually constitute knowledge capital in the form of database, software and similar products within the company. There are legally protected intangible assets which are identified in the trademarks, in patents, in copyright, and the legal protection that characterizes them, makes their content knowable outside, but not imitable by third parties. A further distinction between immaterial assets and intangible resources makes it possible to include the former among the so-called specific intangibles available to the company, and the latter among the general ones. The specific intangibles, which constitute the intangible assets of the company, are autonomously transferable to third parties, identifiable and a significant purchase or production cost must have been incurred. The category of general resources, on the contrary, is very broad and includes the know-how of function and system, namely commercial and technological know-how, organizational knowledge, administrative and management skills, and knowledge of the external economic environment. These resources are firm specific and are represented by all those internal production conditions, which are endogenous and non-identifiable separately from the company. Coyne and Hall hypothesize that competitive advantage reflects asymmetries between companies in terms of differentials in capacity, and classify intangible resources based on the differentials that they have. In particular, they identify: (Coyne, 1986; Hall, 1992)

-Functional differentials, created by the knowledge of those who, inside or outside the company, participate in its value chain, with reference to the available know-how in the company or to the customer portfolio;

-Cultural differentials, fueled by habits, attitudes, beliefs and values shared in the company system, which can effectively influence organizational behavior;

-Positional differentials, built by actions in the past that have produced image, internal and external relations, and organized information;

-Legal differentials, powered by legally protected immaterial assets, such as patents, trademarks, licenses, intellectual property rights, etc.

With reference to these resources, Hall makes two further distinctions. Firstly, he distinguishes immaterial resources into 'skills' and 'assets': those which are considered 'skills', such as individual knowledge and organizational culture, determine the individual and organizational behavior of people; while those that are considered 'assets' represent objects that the company possesses and utilizes (such as legally protected 
immaterial assets). Secondly, the author distinguishes immaterial resources into dependent on and independent of persons: individual knowledge, organizational culture, internal and external relationality are considered dependent on persons; while immaterial assets - legally protected or not - are considered independent of persons. On the basis of what has been said so far, non-material or financial resources of a company can be distinguished in: specific production factors of an immaterial nature, or even immaterial assets acquired outside; immaterial resources or even immaterials that are generated internally and autonomously evaluable; intangible resources i.e. resources that, independently of their origin, cannot be evaluated autonomously. (Grasenick and Low, 2004). Taking into account the various classifications and proposed definitions, it is possible to identify different categories of resources within the corporate assets that can generally be ascribed to the class of intangible resources (general intangibles) and to the class of immaterial resources (specific intangibles). Therefore, while general intangibles represent internal resources that are non-measurable, non-transferable independently and less perceptible from the outside, there are other immaterial resources within and outside the company. Internal resources, if measurable and non-transferable, are those that cannot be separated from the complex they belong to, but if in addition to being measurable they are also transferable, then these are resources that can be quantified in value and thus can be sold. External resources, on the other hand, if transferable and measurable, are real assets identified as immaterial fixed assets on the basis of a purchase cost, and that subsequently can be sold; if transferable, but autonomously non-measurable, they are intangible resources that cannot be quantified individually but can be transferred together with the entire company.

\section{The Intangible}

The basic idea developed by Itami is that there are assets in the enterprise that do not materialize in buildings, plants, products, but are intangible: that is, technological knowledge, corporate image, knowledge accumulated on the market and through consumers, management skills, and corporate culture (Itami, 1987). They are resources based on the accumulation of information and knowledge and their value is difficult to quantify but, if properly managed, not only is it not subject to the use of time, but also is susceptible to a high growth over time. The author believes that the company is at the center of a flow of information that is generated thanks to the presence of individual accumulators and producers of knowledge. Intangible resources therefore include the knowledge acquired by each individual present in the company, all information entering and leaving the company, circulating among the company's stakeholders, outlining an information flow, which is capable of influencing people's abilities and generating also new knowledge ( $\mathrm{Gu}$ and Lev, 2011). There is, therefore, a strong link between intangible resources and human capital (Diefenbach, 2006). Top managers of the companies widen the field by describing the enterprise as a cognitive system whose existence depends mainly on two factors: knowledge (internal factor) and trust (external factor). Knowledge can be observed both in an individual structure and in an organizational structure. The former includes individual knowledge, the skills that distinguish men who work in the company with their own values, professionalism and creativity; the second structure, on the other hand, concerns the skills that can be summarized in know-how, that is, the scientific, technological and commercial heritage that is spread throughout the organization from the external environment. Intangible resources, however, are qualified not only as knowledge resources, but also as resources of trust. Trust is no more than a form of knowledge that reduces the level of uncertainty in exchange relations and can also be described as a stable relation that is generated and strengthened through communication processes. It is an interaction that must be constantly reproduced over time and is self-perpetuating through the creation of stable bonds. In other words, knowledge is expressed and operates through internal and environmental processes, trust through processes which start from the company generate a return flow to the environment. The presence of intangible resources represents a source of success for the company, as they are components difficult to acquire and replicate, being resources usually implemented over time and not easy to purchase externally with the sole help of financial resources. These resources are unique and can substantially differentiate the company from its competitors as they present the character of originality; in fact, in different business situations, intangible resources with the same peculiarities are rarely found. As a matter of fact, these resources are often made within the company, strongly connected to the context in which they are developed and, consequently, present characteristics of specificity that are difficult to reproduce: they are, actually, specific firm resources. Furthermore, intangible resources are also defined as multipurpose, since they can be used simultaneously for different functions. Their contribution, therefore, can be multiple, as they can be exploited simultaneously in different business activities, and bring multiple benefits to the company. They are also characterized by the character of sedimentability, which allows them to be preserved in the "organizational memory", in the company's personnel and in the organisms outside the company. Other distinctive criteria, closely connected with each other, can be found in transferability, in separability and in measurability. Intangible resources must be difficult to imitate or reproduce by competitors: therefore, high levels of transferability do not allow the 
company to achieve certain advantages, as resources are easily accessible to most competitors. Intangible resources, which are specific to the company that generated and developed them, difficult to reproduce and transfer, allow raising barriers to entry that distance the company from the logic of competition. Furthermore, for the purpose of maintaining competitive advantage, it is necessary that the company nourishes the availability of intangible resources over time. Intangible resources are able to attribute value to companies both independently and in a complementary way; in such a manner, by combining with each other and together with the material and immaterial conditions, they enrich the productive combinations and participate in the development of the company's assets.

\section{The Role of Intangible in Italian Companies}

To tackle the changes caused by the crisis, the economy of knowledge needs to increase its intangible resources, also in order not to lose, owing to the crisis, the skills acquired over time. Knowledge and skills affect not only the companies' methods of production, but also their management strategies and relations of competition and cooperation on the market. These resources are the main determinants of growth at the firm level and increasingly constitute the foundation of the competitive power of the company (Cugini et al., 2016). The companies that in these years of economic crisis identified and penetrated new markets, did it by investing mainly in intangibles, which are already today the most important competitive factor and the largest part of business value. To identify the weight that the intangibles have taken on during recent years, let's look at the first national survey carried out in 2013 on intangible investments in Italian companies: the Intangible Assets Survey (Statistical Survey on intangible investments of companies Intangible Assets Survey). In particular, this survey shows the results related to the investment in intangible resources based on the size of the company, the sector in which it operates and its geographical location. The survey highlights that Italian companies in 2012, despite the economic crisis, invested in intangible assets. In fact, the data shows that there is a clear tendency for large companies (95.5\%) to invest in intangible assets (Isfol, 2012). Companies in the industrial sector $(67.3 \%)$ are slightly more likely to face expenses for immaterial investments than those in the service sector $(66.2 \%)$. In terms of territorial allocation, the percentile of intangible investments in the Northern regions is slightly higher than the average $(69.1 \%$ in the North West and $70.3 \%$ in the North East), while being slightly lower in the regions of Central Italy (65.7\%), and significantly lower in the South and Islands with just $54.8 \%$. Among the investments in intangible assets, company training is the most widespread activity: in fact, $37.8 \%$ of companies with 10 or more employees organized one or more training courses in 2012; in second place are the investments in image and branding (34.4\%), followed with a short distance by those in software (32.2\%). The remaining activities have much lower percentages: the company organization involves just over a fifth of the total companies, slightly lower is the percentage of investments in research and development (17\%) and, in the last place, the investment in design, with less than $10 \%$ (Isfol; 2012). In any case, despite the differences in size, sector and territory, it is clear how the intangibles are becoming increasingly important within companies

\section{Intangible and Value Creation}

If the purpose of the enterprise is to create new wealth, it is necessary to understand how intangible resources relate to that and what role they play in the context of this corporate purpose. To achieve this goal, it is possible to use the capital cycle model as a reference point, i.e. the circular process whereby the initial wealth being available to the entrepreneur is invested in production factors with simple productiveness and production factors with repeated productiveness, according to a relation varying from company to company and from sector to sector. These production factors are combined with each other and support products that, once they are sold, allow getting hold of new money capital, which is ready to be reused in a new production cycle (Manca, 2005). The value is generated by the company through a process in which resources transform into new resources, both tangible and intangible, and is defined as the benefit/cost ratio linked to a given activity. It is necessary to make a comparison between the prices-cost of the production factors and the prices-revenue of the products. If the price-cost represents the utility that an acquired factor can have in the production processes and the price-revenue represents the utility received by the customer in relation to a given product, the difference between costs and revenues can produce two effects: a profit for the entrepreneur, or the conferment of an immaterial content to the final product. As a consequence, the customer, in addition to paying the value contained in the materially used factors, will also pay the value of those intangible production conditions, such as technology, know-how, human capital employed in processes and other intangible factors (Sackman, Flamholz, \& Bullen, 1989).

In order for the company to fulfill its economic role of creating value, it is necessary that the value of the goods produced and sold is higher than that of the resources used for production. In this way, the company transforms the possessed resources into new resources of greater value. The intangible resources that contribute to the 
creation of products are not all incorporated in them; a part of these resources remains within the company, contributes to the creation of new intangible resources starting from the cognitive resources accumulated in the past (Baruch, 2003). According to studies that share the interpretation carried out by the Dynamic Capabilities, the competitive advantage is not so much given by the possessed resources as the ability to access, use, exchange and combine them in the best way (Teece et al., 1997). Knowledge is cumulative, every idea is based on the previous one, while the machines wear out and are indebted. The concept of Dynamic Capability summarizes in a single expression two fundamental elements: the term dynamic refers to the ability of an enterprise to renew its skills in order to be in harmony with environmental changes, while the term capability stresses the ability of the strategic management to redefine and integrate resources, knowledge and skills within the company with the external ones, in order to absorb the knowledge originated from the latter and widen its wealth of competences. According to the studies that share the Knowledge-based View (Nonaka \& Takeuchi, 1995), the main resource for the development of the company is identified in the knowledge. According to this point of view, the same corporate organization is conceived as a set of knowledge. The value of companies is no longer created exclusively thanks to the physical characteristics of goods, but the concept of value is extended to that of immateriality; in particular, the value creation process also has something to do with the quality of the entrepreneurial formula used by management and with the quality of individual and organizational knowledge and skills that determine the efficiency of management operations. Nonetheless, intangible resources cooperate with other resources in generating the future income of the company and, therefore, if they are adequately governed and managed, they can play an incisive role in the performance of the company, and figure as the main drivers for the creation of value, with a view to continuity and development of the company.

\section{Final Consideration}

In conclusion, the remarkable importance that the intangible factors have in the corporate economy is understood. These are intangibles based on knowledge and considered as the most important source of business competitiveness, and it is in the phase of their creation, acquisition and enhancement that the value of the company resides rather than in the simple production of tangible goods. From the analysis of the intangible assets of a company and from the various contributions elaborated on the topic, an important relationship emerged within the intangible component, which separates the intangible resources, defined as specific intangibles, from intangible resources in the proper sense, defined as general intangibles instead. The difference between the two types is in the existence or in some particular characteristics, since the specific intangibles are production components without materiality, however generally they are quantifiable, measurable and often transferable separately from the complex company system (such as patents, trademarks, licenses). They are usually acquired upon payment and have their exact identification, detection and evaluation in the financial statements, as required by the provisions of the Civil Code and the accounting standards. The general intangibles, on the other hand, are production components without materiality, characterized by a difficult monetary quantification; they are not the result of a specific investment or purchase and are usually not transferable or separable from the complex management system of the company. Sometimes it is possible to quantify the value through individual components (for instant, in the case of employee's experience, through the evaluation of training costs, or, in the case of manufacturing and technological knowledge and synergies, by quantifying the investments made in research and development), however, most of the time the actual extent of this resource is inseparable from the whole and therefore, is not recorded and recognized in the representation of the financial statements according to the principles established by the law. Intangible assets took an increasing importance in qualifying the attractiveness of a product or service, in spreading know-how, in strengthening the agreements and the collaborations for the joint utilization of the goods themselves. Intangible resources are developed for the business economy with the double nature of 'input', which is of information flows obtained from the environment and of 'output', which is of information flows conveyed by the company towards the environment. for the future, with the aim to craete company value, we believe it is opportune to consider the good association between intangibles and the various components of immaterial resources; this association will be able to guarantee not only the creation la creazione diof value for shareholders, but also for all the subjects direcly and indirectly involved in the life of the company as well as the survival and reputation of the company itself. Our research is limited to participating in the wide debate on intangibles and immaterial resources considering their important role at company level and at the level of economy. . However, it can be stated that today studies on intangibles have not achieved a universally accepted definition noeither do they indicate clearly how they stessi contribute to improve company performances also because they vary according to the type of company object of this study. 


\section{References}

Ahonen, G. (2000). Generative and commercially exploitable intangible assets. Classification of intangibles ((pp. 206-213). Jouy-en-Josas, Groupe HEC.

Barney, J. (1991). Firm resources and sustained competitive advantage. Journal of Management, 17(1), 99-120. Thousand Oaks, California. https://doi.org/10.1177/014920639101700108

Baruch, L. (2003). Intangibles. Gestione, valutazione e reporting delle risorse intangibili delle aziende. Etas libri.

Bernard, M. (2005). Strategic management of intangible value drivers. Handbook of Business Strategy, 6(1), 147-154. https://doi.org/10.1108/08944310510557161

Bontis, N. (2002). Managing Organizational Knowledge by Diagnosing IntellectualCapital. In C.W. Choo \& N. Bontis (Eds.), The Strategic Management of Intellectual Capital and Organizational Knowledge (pp. 621-642). Oxford University Press.

Bresciani, S., \& Ferraris, A. (2012). Imprese multinazionali. Innovazione e scelte localizzative. Maggioli.

Carlucci, D., \& Schiuma, G. (2007). Assessing the role of knowledge assets in value creation dynamics by using the Analytic Network Process. Paper presented at the IC Congress, Amsterdam.

Coyne, K. (1986). Sustainable Competitive Advantage. What it is, what it isn't. Business Horizions.

Cugini, A., Dossi, A., Ghezzi, L., \& Derchi, G. B. (2016). Strategia, azioni, misure: Modelli di successo di performance management per le imprese italiane. Egea, Milano

Dameri, R. (2003). Intangibles e informativa volontaria. In: Mancini, D. Quagli, A. Marchi, L. (a cura di). Gli intangibles e la comunicazione d'impresa. Milano, FrancoAngeli, (pp. 289-327).

Diefenbach, T. (2006). Intangible resources: A categorial system of knowledge and other intangible assets. Journal of Intellectual Capital, 7(3), 406-420. https://doi.org/10.1108/14691930610681483

Edvinsson, L., \& Malone, M. S. (1997). Intellectual capital: realizing your company's true value by findings its hidden brainpower. New York: HarperCollins publishers.

Grant, R. M. (1991). The Resource-Based Theory of Competitive Advantage: Implications for Strategy Formulation. California Management Review, 33(3), 14-35. https://doi.org/10.2307/41166664

Grasenick, K., \& Low, J. (2004). Shaken, not stirred: defining and connecting indicators for the measurement and valuation of intangibles. Journal of Intellectual Capital, 5(2), 268-281. https://doi.org/10.1108/14691930410533696

Gu, F., \& Lev, B. (2011). Intangible assets: Measurement, drivers, and usefulness. In G. Schiuma (Ed.), Managing knowledge assets and business value creation in orga-nizations: Measures and dynamics (pp. 110-124). New York: IGI Global snippet.

Hall, B. H., Jaffe, A., \& Trajtenberg, M. (2001). Market value and patent citations: A first look. University of California at Berkley working papers, Department of Economics. Retrieved from http://repositories.cdlib.org/iber/econ/E01-304

Hall, R. (1992). The Strategic Analysis of Intangibles Resources. Strategic Management Journal, 13. https://doi.org/10.1002/smj.4250130205

Itami, H. (1987). Mobilizing Intangible Assets. Cambridge: Harvard University Press.

Lee, R. P., \& Chen, Q. (2009). The immediate impact of new product introductionson stock price: The role of firm resources and size. Journal of Product Innovation Management, 26, 97-107. https://doi.org/10.1111/j.1540-5885.2009.00337.x

Lev, B. (2003). Intangibles: Management, Measurement, and Reporting. Moscow: Cwinto-Consalting.

Manca, F. (2005). Il valore di bilancio degli intangible asset. Cedam, Padova.

Miller, T. W., \& Mathisen, R. E. (2008). Contributions of advertising assets and R\&Dassets to the market value of firm. Advances in Accounting, Finance and Economics, 1, 1-14.

Nonaka, I., \& Takeuchi, H. (1995). The Knowledge-Creating Company: How Japanese Companies Create the Dynamics of Innovation. New York: Oxford University Press.

Ochs, P. (1995). L'investissement immatériel et la commercialisation : Analyse du cas français. Thèse pour le 
doctorat en Sciences de Gestion, Université Paris II - Panthéon-Assas.

Rullani, E. (1992). Economia delle risorse immateriali: una introduzione. Sinergie, 2.

Sackman, S., Flamholz, E., \& Bullen, M. (1989). Human resource accounting. A stateof the art review. Journal of Accounting Literature, 8, 235-264).

Stewart, T. A. (1997). Intellectual capital: The new wealth of organizations. New York: Doubleday/Currency.

Sveiby, K. E. (1997). The new organizational wealth: Managing \& measuring knowledge-based assets. San Francisco: Berrett-Koehler Publishers.

Tanfous, M. B. (2013). The Contribution of Intangibles to the Value Creation. Journal of Business Studies Quarterly, 5(1).

Teece, D. J., Pisano, G., \& Shuen, A. (1997). Dynamic Capabilities and Strategic Management. Strategic $\begin{array}{llll}\text { Management } & \text { Journal, } & \text { 18(7), } & \text { 509-533. }\end{array}$ https://doi.org/10.1002/(SICI)1097-0266(199708)18:7<509::AID-SMJ882>3.0.CO;2-Z

Villalonga, B. (2004). Intangible resources, Tobin's q, and sustainability of performance differences. Journal of Economic Behavior \& Organization, 54(2), 205-230. https://doi.org/10.1016/j.jebo.2003.07.001

\section{Copyrights}

Copyright for this article is retained by the author(s), with first publication rights granted to the journal.

This is an open-access article distributed under the terms and conditions of the Creative Commons Attribution license (http://creativecommons.org/licenses/by/4.0/). 